\title{
Receptor for advanced glycation end-products and environmental exposure related obstructive airways disease: a systematic review
}

\author{
Syed H. Haider ${ }^{1,2}$, Assad Oskuei ${ }^{1}$, George Crowley ${ }^{1}$, Sophia Kwon ${ }^{1}$, \\ Rachel Lam ${ }^{1}$, Jessica Riggs ${ }^{1}$, Mena Mikhail ${ }^{1}$, Angela Talusan ${ }^{1}$, Arul Veerappan ${ }^{1}$, \\ James S. Kim ${ }^{1}$, Erin J. Caraher ${ }^{1}$ and Anna Nolan ${ }^{1,2,3}$ \\ Affiliations: ${ }^{1}$ Dept of Medicine, Division of Pulmonary, Critical Care and Sleep Medicine, New York University \\ School of Medicine, New York, NY, USA. ${ }^{2}$ Bureau of Health Services and Office of Medical Affairs, Fire \\ Department of New York, New York, NY, USA. ${ }^{3}$ Dept of Environmental Medicine, New York University School \\ of Medicine, New York, NY, USA. \\ Correspondence: Anna Nolan, New York University School of Medicine, Dept of Medicine, Division of \\ Pulmonary, Critical Care and Sleep, New Bellevue, 462 1st Avenue, New York, NY 10016, USA. \\ E-mail: anna.nolanđamed.nyu.edu
}

@ERSpublications

RAGE is biologically relevant in environmental exposure associated lung disease. Future investigations should focus on further understanding the role and therapeutic potential of RAGE in particulate matter exposure associated lung disease http://ow.ly/gfZz30o7otU

Cite this article as: Haider SH, Oskuei A, Crowley G, et al. Receptor for advanced glycation end-products and environmental exposure related obstructive airways disease: a systematic review. Eur Respir Rev 2019; 28: 180096 [https://doi.org/10.1183/16000617.0096-2018].

\section{ABSTRACT}

Background: Our group has identified the receptor for advanced glycation end-products (RAGE) as a predictor of World Trade Center particulate matter associated lung injury. The aim of this systematic review is to assess the relationship between RAGE and obstructive airways disease secondary to environmental exposure. Methods: A comprehensive search using PubMed and Embase was performed on January 5, 2018 utilising keywords focusing on environmental exposure, obstructive airways disease and RAGE and was registered with PROSPERO (CRD42018093834). We included original human research studies in English, focusing on pulmonary end-points associated with RAGE and environmental exposure.

Results: A total of 213 studies were identified by the initial search. After removing the duplicates and applying inclusion and exclusion criteria, we screened the titles and abstracts of 61 studies. Finally, 19 fulltext articles were included. The exposures discussed in these articles include particulate matter $(\mathrm{n}=2)$ and cigarette smoke $(n=17)$.

Conclusion: RAGE is a mediator of inflammation associated end-organ dysfunction such as obstructive airways disease. Soluble RAGE, a decoy receptor, may have a protective effect in some pulmonary processes. Overall, RAGE is biologically relevant in environmental exposure associated lung disease. Future investigations should focus on further understanding the role and therapeutic potential of RAGE in particulate matter exposure associated lung disease.

This article has supplementary material available from err.ersjournals.com

This study is registered at PROSPERO with identifier number CRD42018093834.

Provenance: Submitted article, peer reviewed.

Received: Oct 152018 | Accepted after revision: Feb 092019

Copyright $\odot$ ERS 2019. This article is open access and distributed under the terms of the Creative Commons Attribution Non-Commercial Licence 4.0. 


\section{Background}

Obstructive airway disease (OAD) due to environmental exposure is a global health concern [1-3]. Mounting evidence supports the role of receptor for advanced glycation end-products (RAGE), also known as the advanced glycation end-product receptor (AGER), in the development of OAD [4-6].

RAGE is a member of the immunoglobulin superfamily and has several isoforms which recognise pathogens and endogenous ligands. RAGE is at the highest baseline level in the lungs, where it is expressed by alveolar type epithelial cells, alveolar macrophages and the smooth muscle cells of the airways $[7,8]$. The membrane bound form is a key mediator of inflammation, metabolic dysfunction and vascular injury [9-11].

Given its pro-inflammatory role and abundance in the lungs, RAGE has been shown to be an important biomarker of airflow obstruction in various diseases such as cystic fibrosis, asthma, chronic obstructive pulmonary disease (COPD) and particulate matter (PM)-associated OAD [12-16]. Furthermore, RAGE has been implicated in a murine smoke-exposure model of emphysema [17].

In human subjects with $\mathrm{OAD}$, explanted lungs were noted to have increased expression and bronchoalveolar lavage (BAL) levels of RAGE $[4,18]$. In addition, the association between RAGE and OAD has been studied at the genomic level. Single nucleotide polymorphisms within the AGER locus have been linked to forced expiratory volume in $1 \mathrm{~s}(\mathrm{FEV} 1)$ in two genome-wide association studies (GWAS) [19, 20]. AGER-associated loci using in vitro models have been investigated to further our understanding of possible mechanisms. The promoter variant AGER-429 T/C (rs1800625) is associated with severity of airflow obstruction in cystic fibrosis and cells with this functional variant have elevated RAGE expression [21-23].

While the membrane-bound form of RAGE has been implicated in airway inflammation and obstruction, the circulating soluble form (s)RAGE has been shown to act as a decoy receptor. Studies show that OAD, particularly COPD, is associated with reduced levels of circulating sRAGE $[12,13]$. The utility of sRAGE as a diagnostic biomarker in OAD is currently being investigated [14, 24]. The exact correlation of sRAGE and lung disease appears to vary depending on the pulmonary insult. There is evidence that sRAGE is involved in pathogenesis of acute lung injury (ALI). One study showed that sRAGE was inversely correlated with the rate of alveolar fluid clearance [25]. In a direct ALI model elevated sRAGE levels were seen in BAL samples $24 \mathrm{~h}$ after lipopolysaccharide-induced injury. Furthermore, treatment with mouse recombinant sRAGE $1 \mathrm{~h}$ post-injury attenuated neutrophilic infiltration, inflammatory mediator production and alveolar capillary permeability [26]. A subsequent study showed that RAGE was only elevated in BAL fluid of mice with direct ALI compared to an indirect ALI model [27].

The role of RAGE has been examined in several occupational lung diseases as well as pulmonary fibrosis. Some studies have suggested a protective effect, as evidenced by low expression of RAGE and sRAGE in human and mouse models of pulmonary fibrosis $[28,29]$. Consistent with this hypothesis, mice deficient in Ager $\left(\mathrm{Ager}^{-/-}\right)$develop rapidly progressive fibrosis with asbestos exposure [30]. In contrast, another study showed that Ager $^{-/-}$mice exhibited less fibrosis when exposed to bleomycin as compared to wild-type controls [31]. Furthermore, Ager $^{-/-}$mice do not demonstrate any difference in the severity of fibrosis with silica exposure [30]. In models of atopic asthma, Ager $^{-1-}$ mice did not demonstrate airway hypersensitivity, eosinophilic inflammation and airway remodelling. In fact, Ager inhibition in wild-type mice significantly reduced inflammation [15].

Finally, our group has identified elevated serum lysophosphatidic acid (LPA), a product of low-density lipoprotein and a known ligand of RAGE and sRAGE, as World Trade Center-Lung Injury (WTC-LI) biomarkers in the Fire Department of New York (FDNY) cohort [32-34]. Therefore, we have focused this systematic review on RAGE, a biologically plausible mediator and biomarker of environmentally associated OAD.

\section{Methods}

Review strategy

A systematic review of the literature was performed adhering to the Preferred Reporting Items for Systematic Reviews and Meta-analysis (PRISMA) guidelines [35, 36]. Our population, intervention, control, outcome (PICO) question was "In adult patients with obstructive airways disease (P), we performed a systematic review to identify (I) the role of the advanced glycation end-products receptor in subjects whose OAD is secondary to an environmental exposure $(\mathrm{O})$ ". Given the design of our systematic review, no comparison control (C) was needed. PubMed and Embase were searched on January 5, 2018. The details of the protocol of our systematic review were registered on PROSPERO (CRD42018093834) and can be accessed at www.crd.york.ac.uk/prospero/display_record.php?RecordID=93834.

\section{Search terms}

Databases were searched for the following: (particulate matter OR air pollutants OR air pollution OR occupational pollution OR environmental pollution OR ambient air OR pollution OR particle size OR air 
filters OR smoking OR cigarette smoke) AND (advanced glycation end products receptor or rage or ager) AND (lung OR respiratory OR lung diseases OR obstructive lung disease OR obstructive airway disease OR obstructive airways disease OR asthma OR chronic bronchitis OR COPD OR chronic obstructive pulmonary disease OR emphysema).

For the purposes of this review, we defined obstructive airways diseases to include asthma, emphysema, chronic bronchitis and COPD; environmental exposures included cigarette smoke, particulate matter/dust, air or other occupational pollution. We chose to include cigarette use as an environmental exposure, since there is literature that passive smoking or environmental tobacco smoke is associated with an increased risk of COPD similar to direct tobacco use [37-39].

We included studies that 1) discussed advanced glycation end products receptor or any of its isoforms in the setting of OAD due to environmental exposures and 2) assessed OAD development after environmental exposure. We excluded studies that 1) were not original research; 2) not written in the English language; 3) focused on non-human subjects or in vitro work; or were 4) conducted in a paediatric population.

\section{Data extraction}

Each article was screened for study design, patient characteristics, sample size, tools used, severity and prevalence of OAD. Results from each database search were filtered for human subjects and English language, and imported into EndNote X8 (Clarivate Analytics, Philadelphia, PA, USA). The references were then screened for duplicates using RefWorks (ProQuest LLC, Ann Arbor, MI, USA). Only original research papers were then reviewed (title, abstract and full text) to ascertain eligibility. In addition, we examined the references cited in the relevant articles. All results were screened by SHH and further independently evaluated by AN and AO. Disagreements were resolved by consensus (supplementary tables S1-S5).

\section{Results/synthesis}

Study inclusion, characteristics and sources of bias

A total of 213 studies were identified from PubMed, Embase and reference-list screening (figure 1). After application of selection criteria, 61 research papers were assessed for inclusion. Of these, 41 were excluded after the initial review. Finally, 19 original research articles were considered eligible to be included. There are two types of environmental exposures discussed in these articles, particulate matter $(n=2)$ and cigarette smoke $(n=17)$. Of these, six investigations discuss RAGE as a biomarker of OAD activity, seven evaluate the association of RAGE with OAD, four are GWAS discussing RAGE and its isoforms in COPD and smoking, and two discuss the role of RAGE in multiple end-organ outcomes. Data from all searches, screening and extraction are available (table 1 and supplementary table S1).

\section{RAGE in the context of particulate matter exposure}

Autophagy is critical in the pathogenesis of PM-related COPD, leading to impairment of diffusion. One retrospective study in Taiwan investigated the association of clinically relevant biomarkers in COPD patients (Global Initiative for Chronic Obstructive Lung Disease stages III/IV) exposed to particles with a 50\% cut-off aerodynamic diameter of $10 \mu \mathrm{m}$ (PM10). The 1-year average PM10 exposure was positively correlated with interleukin (IL)-6, ubiquitin and beclin-1 levels, and negatively correlated with diffusing capacity of the lung for carbon monoxide (DLCO), circulating RAGE level and arterial oxygen saturation [41]. Recently, our group studied the role of sRAGE in the WTC-PM exposed firefighters as well as in a murine model of PM exposure. sRAGE is associated with WTC-LI in humans and mice alike, and in the murine model, absence of RAGE was protective against loss of lung function and airway hyperreactivity due to WTC-PM exposure [6].

\section{RAGE as a biomarker of emphysema}

Studies have evaluated sRAGE as a potential diagnostic biomarker in order to avoid chest imaging and possibly detect emphysema at earlier stages $[18,51-53]$. A prior systematic review concluded that sRAGE is a strong biomarker of emphysema, but only in patients with airflow limitation [14]. Furthermore, peripheral plasma samples of individuals from the COPDGene population have been assessed for the association of specific biomarkers with emphysema noted on computed tomography (CT) imaging (percentage low lung attenuation $\leqslant-910 \mathrm{HU}$ ). Patients with more emphysema had lower sRAGE and intercellular adhesion molecule-1 levels [45]. These results were further validated in the Treatment of Emphysema with a Gamma-Selective Retinoid Agonist (TESRA) cohort [45] (table 1).

\section{RAGE correlates with severity of emphysema}

In the Evaluation of COPD Longitudinally to Identify Predictive Surrogate Endpoints (ECLIPSE) cohort of COPD patients, the change in CT lung density and severity of emphysema over the study period was 


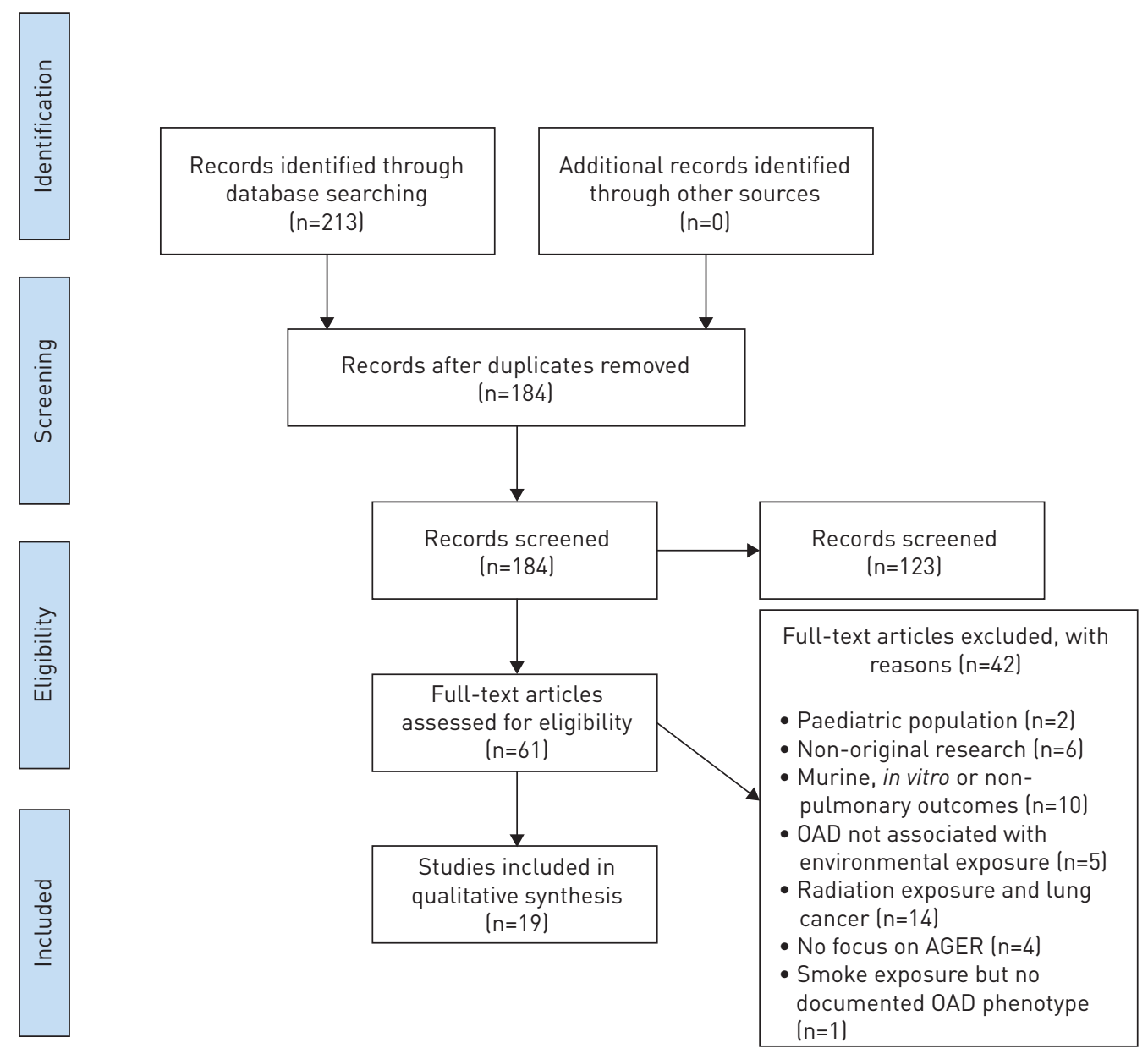

FIGURE 1 Flow diagram as per PRISMA (Preferred Reporting Items for Systematic Reviews and Meta-Analyses) guidelines [40]. OAD: obstructive airways disease; AGER: advanced glycation end-product receptor.

correlated with a number of circulating biomarkers. At baseline, patients with higher levels of sRAGE and surfactant protein D had less emphysema, while lower levels of CCL-18 correlated with more severe disease. Elevated sRAGE, fibrinogen and IL-6 levels at baseline were associated with less progression of emphysema [48].

In another study, serum samples of patients with stable COPD, smokers without COPD and nonsmoking controls were compared for specific biomarkers. Extracellular RAGE-binding protein (EN-RAGE) and sRAGE levels were significantly different between those groups as well as at various stages of COPD. Overall, sRAGE levels were reduced in COPD patients and were more associated with variability in DLCO values. On the contrary, EN-RAGE levels were significantly elevated in severe COPD and more associated with FEV1 and FEV1/forced vital capacity (FVC) values. These findings suggest that sRAGE and EN-RAGE may affect different lung function measures (airway obstruction or diffusion capacity) [49] (tables 1 and 2).

\section{Role of SRAGE in WTC-PM exposed firefighters}

Our group has identified RAGE as a biomarker of WTC-PM induced FEV1 decline. Using a case-cohort design, we studied a cohort of never-smoking male FDNY firefighters exposed to WTC dust with normal pre-9/11 lung function. The odds of developing WTC-LI increased by 1.2, 1.8 and 1.0 in firefighters with sRAGE $\geqslant 97 \mathrm{pg} \cdot \mathrm{mL}^{-1}$, C-reactive protein $\geqslant 2.4 \mathrm{mg} \cdot \mathrm{L}^{-1}$ and matrix metalloproteinase $9 \geqslant 397 \mathrm{ng} \cdot \mathrm{mL}^{-1}$, respectively. We concluded that increased sRAGE is associated with WTC-LI [6] (tables 1 and 2).

\section{RAGE is a biomarker of vascular injury}

A pilot study examined patients with COPD, smokers without COPD and nonsmokers who had renal biopsy or nephrectomy. They measured AGE-RAGE and tissue oxidative stress levels in pulmonary and renal endothelial cells and showed that they were indeed elevated in the COPD group. In addition, they 
TABLE 1 Relevance of the receptor for advanced glycation end-products (RAGE) in obstructive airways disease secondary to environmental exposure

\begin{tabular}{|c|c|c|c|c|c|c|}
\hline $\begin{array}{l}\text { First author, } \\
\text { year [ref] }\end{array}$ & Country & $\begin{array}{l}\text { Population/exposure } \\
\text { /design }\end{array}$ & $\begin{array}{l}\text { Study size } \\
\text { (number of } \\
\text { subjects) }\end{array}$ & Specimen/assay & End-points & Significant findings \\
\hline $\begin{array}{l}\text { Caraher, } \\
2017[6]\end{array}$ & USA & $\begin{array}{l}\text { FDNY, WTC-PM, case } \\
\text { cohort }\end{array}$ & 185 & Serum/Luminex & FEV 1 & $\begin{array}{l}\text { Odds of developing WTC-LI increased by } 1.2 \text {, } \\
1.8 \text { and } 1.0 \text { in firefighters with sRAGE } \\
\geqslant 97 \mathrm{pg} \cdot \mathrm{mL}^{-1}, \text { CRP } \geqslant 2.4 \mathrm{mg} \cdot \mathrm{L}^{-1} \text { and MMP-9 } \\
\leqslant 397 \mathrm{ng} \cdot \mathrm{mL}^{-1} \text {, respectively }\end{array}$ \\
\hline $\begin{array}{l}\text { Lee, } 2016 \\
\quad[41]\end{array}$ & Taiwan & $\begin{array}{l}\text { COPD, PM10, } \\
\text { retrospective case- } \\
\text { control }\end{array}$ & 58 & Serum, ELISA & $\begin{array}{c}\mathrm{FVC}, \mathrm{FEV} / / \mathrm{FVC}, \mathrm{RV} / \mathrm{TLC}, D \mathrm{LCO} \\
\Delta \mathrm{SaO}_{2} \\
\text { 8-isoprostane, } \\
\text { IL-6, RAGE, carbonyl oxidation, } \\
\text { ubiquitin, proteasome, beclin-1 }\end{array}$ & $\begin{array}{l}\text { Exposure to elevated levels of PM10 was } \\
\text { associated with reduced circulating RAGE } \\
\text { levels }\end{array}$ \\
\hline $\begin{array}{l}\text { Polverino, } \\
2017[42]\end{array}$ & USA & $\begin{array}{l}\text { COPD, cigarette } \\
\text { smoke, longitudinal }\end{array}$ & 82 & $\begin{array}{l}\text { Lung, } \\
\text { IHC }\end{array}$ & $\begin{array}{c}\text { UACR, eGFR, } \\
\text { AGE-RAGE in pulmonary/renal ECs }\end{array}$ & $\begin{array}{l}\text { Timmunostaining of AGE and RAGE in ECs of } \\
\text { COPD cases }\end{array}$ \\
\hline $\begin{array}{l}\text { Hoonhorst, } \\
2016[43]\end{array}$ & $\begin{array}{l}\text { The } \\
\text { Netherlands }\end{array}$ & $\begin{array}{l}\text { COPD, cigarette } \\
\text { smoke, longitudinal }\end{array}$ & 288 & $\begin{array}{l}\text { blood/sputum/bronchial } \\
\text { biopsies, ELISA/IHC }\end{array}$ & $\begin{array}{l}\text { AGE, sRAGE, } \\
\text { lung function }\end{array}$ & $\begin{array}{l}\text { Low sRAGE is associated with COPD and } \\
\text { impaired lung function }\end{array}$ \\
\hline $\begin{array}{l}\text { John, } 2016 \\
\quad[44]\end{array}$ & UK & $\begin{array}{l}\text { COPD, cigarette } \\
\text { smoke, } \\
\text { cross-sectional }\end{array}$ & 291 & Blood, IHC & $\begin{array}{l}\text { PWV, BP, skin autofluorescence, } \\
\text { sRAGE, lipids }\end{array}$ & $\begin{array}{l}\text { Cardiovascular risk prediction score and } \\
\text { SRAGE levels were the same COPD and } \\
\text { non-COPD smokers }\end{array}$ \\
\hline $\begin{array}{l}\text { Carolan, } \\
2014[45]\end{array}$ & USA & $\begin{array}{l}\text { COPDGene, cigarette } \\
\text { smoke, } \\
\text { cross-sectional }\end{array}$ & 588 & $\begin{array}{c}\text { Plasma, custom assay by } \\
\text { Myriad-RBM }\end{array}$ & \%LAA, LP15A, sRAGE & $\begin{array}{l}\text { Patients with more emphysema had lower } \\
\text { SRAGE and ICAM1 levels }\end{array}$ \\
\hline $\begin{array}{l}\text { Iwamoto, } \\
2014[46]\end{array}$ & Finland & $\begin{array}{l}\text { COPD, cigarette } \\
\text { smoke, longitudinal }\end{array}$ & 295 & Plasma & FEV $1, F V C, F E V_{1} / F V C$, sRAGE & $\begin{array}{l}\text { Lower sRAGE predicts greater progression of } \\
\text { airflow obstruction }\end{array}$ \\
\hline $\begin{array}{l}\text { Chen, } 2014 \\
\text { [47] }\end{array}$ & China & $\begin{array}{l}\text { COPD, cigarette } \\
\text { smoke, ex-vivo }\end{array}$ & 40 & $\begin{array}{l}\text { Lung, } \mathrm{HBE} / \mathrm{IHC} / \mathrm{ELISA} / \\
\text { Western blot }\end{array}$ & $\begin{array}{c}\text { FEV1, FVC, FEV1/FVC, RAGE, } \\
\text { NO generation }\end{array}$ & $\begin{array}{l}\text { Overexpression of RAGE contributes to } \\
\text { smoking-induced NO generation in COPD }\end{array}$ \\
\hline $\begin{array}{l}\text { Coxson, } 2013 \\
\quad[48]\end{array}$ & Multiple & $\begin{array}{l}\text { ECLIPSE, cigarette } \\
\text { smoke, longitudinal }\end{array}$ & 1285 & Serum, ELISA & Lung density on CT scan & $\begin{array}{l}\text { Elevated sRAGE, fibrinogen and IL- } 6 \text { levels at } \\
\text { baseline were associated with less } \\
\text { progression of emphysema }\end{array}$ \\
\hline $\begin{array}{l}\text { Cockayne, } \\
2012[49]\end{array}$ & Germany & $\begin{array}{l}\text { COPD, cigarette } \\
\text { smoke, prospective } \\
\text { observational study }\end{array}$ & 185 & $\begin{array}{l}\text { Serum, } \\
\text { multiplex }\end{array}$ & $\begin{array}{l}\mathrm{FEV} 1, \mathrm{FEV} 1 / \mathrm{FVC} \\
D\left\llcorner\mathrm{CO}_{1}, 142 \text { analytes }\right.\end{array}$ & $\begin{array}{l}\text { SRAGE and EN-RAGE were two out of seven } \\
\text { biomarkers that showed significant } \\
\text { differences between severe/very severe } \\
\text { COPD, mild/moderate COPD, smoking and } \\
\text { nonsmoking control groups; sRAGE and } \\
\text { EN-RAGE affect different lung function } \\
\text { measures }\end{array}$ \\
\hline $\begin{array}{l}\text { Miniati, } 2011 \\
\text { [50] }\end{array}$ & Italy & $\begin{array}{l}\text { COPD, } \\
\text { cigarette smoke, } \\
\text { case-control }\end{array}$ & 401 & $\begin{array}{l}\text { Plasma, } \\
\text { ELISA }\end{array}$ & $\begin{array}{c}\mathrm{FEV}_{1}, \mathrm{FEV}_{1} / \mathrm{FVC}, \text { DLco, emphysema } \\
\text { severity, sRAGE }\end{array}$ & $\begin{array}{l}\text { SRAGE is significantly lower in patients with } \\
\text { COPD than in age- and sex-matched } \\
\text { individuals without obstruction } \\
\text { Emphysema is an independent predictor of } \\
\text { reduced SRAGE in COPD }\end{array}$ \\
\hline $\begin{array}{l}\text { Ohlmeier, } \\
2010[51]\end{array}$ & Finland & IPF/UIP/COPD/AAT & 49 & $\begin{array}{c}\text { Lung, } \\
\text { 2-dimensional } \\
\text { electrophoresis, mass } \\
\text { spectrometry, Western } \\
\text { blot, ELISA }\end{array}$ & RAGE & $\begin{array}{l}\text { Three RAGE variants (FL-RAGE, cRAGE, } \\
\text { esRAGE) are important in IPF. The decline } \\
\text { of FL-RAGE and CRAGE, but not esRAGE, in } \\
\text { COPD lungs is evidence of the involvement } \\
\text { of specific RAGE variants in this disease }\end{array}$ \\
\hline
\end{tabular}




\begin{tabular}{|c|c|c|c|c|c|c|}
\hline $\begin{array}{l}\text { First author, } \\
\text { year [ref] }\end{array}$ & Country & $\begin{array}{l}\text { Population/exposure } \\
\text { /design }\end{array}$ & $\begin{array}{l}\text { Study size } \\
\text { (number of } \\
\text { subjects) }\end{array}$ & Specimen/assay & End-points & Significant findings \\
\hline $\begin{array}{l}\text { Ferhani, } \\
2010[18]\end{array}$ & France & $\begin{array}{c}\text { COPD, } \\
\text { cigarette smoke, N/A }\end{array}$ & 70 & $\begin{array}{c}\text { Lung, } \\
\text { Western blot, ELISA, } \\
\text { Luminex, IHC, BAL, EC, } \\
\text { AM }\end{array}$ & HMGB1, IL-1 $\beta$, RAGE & $\begin{array}{l}\text { Elevated HMGB1 expression in COPD airways } \\
\text { may sustain inflammation and remodelling } \\
\text { through its interaction with IL-1 } 1 \beta \text { and RAGE }\end{array}$ \\
\hline $\begin{array}{l}\text { Zhang, } 2014 \\
\text { [52] }\end{array}$ & China & $\begin{array}{l}\text { COPD, } \\
\text { cigarette smoke, N/A }\end{array}$ & 102 & Plasma/serum, ELISA & $\begin{array}{c}\text { FEV1, FEV1/FVC, HMGB1, sRAGE, } \\
\text { hsCRP, fibrinogen }\end{array}$ & $\begin{array}{l}\text { HMGB1 and sRAGE levels were dynamically } \\
\text { changed between exacerbation and } \\
\text { convalescence phases of COPD }\end{array}$ \\
\hline $\begin{array}{l}\text { Boschetto, } \\
2013[53]\end{array}$ & Italy & $\begin{array}{l}\text { COPD, CHF, COPD + } \\
\text { CHF, cigarette smoke, } \\
\text { N/A }\end{array}$ & 143 & $\begin{array}{l}\text { Plasma, } \\
\text { ELISA }\end{array}$ & sRAGE, CML, BNP & $\begin{array}{l}\text { Plasma levels of sRAGE and CML are } \\
\text { increased in CHF, but not COPD patients }\end{array}$ \\
\hline $\begin{array}{l}\text { Cho, } 2015 \\
{[54]}\end{array}$ & Multiple & $\begin{array}{l}\text { COPDGene, ECLIPSE, } \\
\text { NETT, GenKOLS, } \\
\text { cigarette smoke, N/A }\end{array}$ & 12031 & GWAS & Loci associated with emphysema & $\begin{array}{l}\text { The AGER locus was related to an } \\
\text { emphysematous phenotype }\end{array}$ \\
\hline $\begin{array}{l}\text { Hardin, } 2012 \\
\text { [55] }\end{array}$ & Poland & $\begin{array}{l}\text { COPD, } \\
\text { cigarette smoke, N/A }\end{array}$ & 645 & $\begin{array}{l}\text { Blood, } \\
\text { TaqMan }\end{array}$ & $\begin{array}{c}\text { FEV } 1, F E V_{1} / F V C, \text { SNPs } \\
\text { COPD and COPD-associated } \\
\text { phenotypes, SNPs previously } \\
\text { associated with lung function in } \\
\text { GWAS and COPD were assessed }\end{array}$ & $\begin{array}{l}\text { In patients with severe COPD, there is an } \\
\text { association between two SNPs previously } \\
\text { associated with COPD (CHRNA3/5 and } \\
\text { IREB2), as well as an association with } \\
\text { COPD of one locus initially associated with } \\
\text { lung function (ADCY2) }\end{array}$ \\
\hline Li, $2014[56]$ & China & $\begin{array}{c}\text { COPD, } \\
\text { cigarette smoke, N/A }\end{array}$ & 455 & $\begin{array}{l}\text { WBC genomic DNA/ } \\
\text { PCR-RFLP }\end{array}$ & FEV1, FVC, FEV $1 / F V C$ & $\begin{array}{l}\text { G82S polymorphism in the RAGE gene is } \\
\text { associated with increased risk of COPD; GS } \\
\text { genotype of the G82S variant is a COPD } \\
\text { risk factor }\end{array}$ \\
\hline $\begin{array}{l}\text { Miller, } 2016 \\
\text { [57] }\end{array}$ & UK & $\begin{array}{c}\text { COPD, } \\
\text { cigarette smoke, N/A }\end{array}$ & 992 & $\begin{array}{c}\text { Lung/serum, IHC, PCR, } \\
\text { ELISA }\end{array}$ & $\begin{array}{c}\text { Alveolar RAGE, } \\
\text { AGER splicing, sRAGE }\end{array}$ & $\begin{array}{l}\text { AGER splicing, Ser } 82 \text { allele associated with } \\
\text { increased FEV } 1 \text { and FEV } 1 / F V C \text { ratio and } \\
\text { decreased SRAGE }\end{array}$ \\
\hline
\end{tabular}

FDNY: Fire Department of New York; WTC-PM: World Trade Center-particulate matter; FEV1: forced expiratory volume in $1 \mathrm{~s}$; WTC-LI: WTC lung injury; sRAGE: soluble RAGE; CRP: C-reactive protein; MMP: matrix metalloproteinase; COPD: chronic obstructive pulmonary disease; PM10: particulate matter <10 $\mu \mathrm{m}$ in aerodynamic diameter; FVC: forced vital capacity; RV: residual volume; TLC: total lung capacity; DLCO: diffusing capacity of the lung for carbon monoxide; $\triangle \mathrm{SaO}_{2}$ : change in arterial oxygen saturation; IL: interleukin; IHC: immunohistochemistry; UACR: urinary albumin/creatinine ratio; eGFR: estimated glomerular filtration rate; AGE: advanced glycation end-products; EC: endothelial cells; PWV: pulse wave velocity; BP: blood pressure; \%LAA: percentage low lung attenuation; LP15A: 15th percentile on lung attenuation curve; ICAM: intercellular adhesion molecule; HBE: human bronchial epithelial cells; NO: nitric oxide; ECLIPSE: Evaluation of COPD Longitudinally to Identify Predictive Surrogate Endpoints; CT: computed tomography; EN-RAGE: extracellular RAGE-binding protein; IPF: idiopathic pulmonary fibrosis; UIP: usual interstitial pneumonia; AAT: $\alpha_{1}$-antitrypsin; FL-RAGE: full-length RAGE; cRAGE: C-terminal processed RAGE; esRAGE: endogenous secretory RAGE; N/A: not applicable; BAL: bronchoalveolar lavage; AM: alveolar macrophages; HMGB: high mobility group box; hsCRP: high-sensitivity CRP; CHF: congestive heart failure: CML: N-(carboxymethyl) lysine adducts; BNP: brain natriuretic peptide; NETT: National Emphysema Treatment Trial: GenKOLS: Genetics of Chronic Obstructive Lung Disease: GWAS: genome-wide association studies; AGER: advanced glycation end-products receptor; SNP: single nucleotide polymorphism; CHRNA: cholinergic receptor nicotinic $\alpha 1$ subunit; IREB: iron-responsive element-binding protein; ADCY: adenylate cyclase; WBC: white blood cell count; RFLP: restriction fragment length polymorphism. 
TABLE 2 Associations between receptor for advanced glycation end-products (RAGE), soluble (s)RAGE and disease state

\begin{tabular}{|c|c|c|c|}
\hline & RAGE & sRAGE & Summary \\
\hline OAD & Positive & Negative & $\begin{array}{l}\text { Lungs of patients with OAD (COPD and CF) have increased levels of RAGE }[4,21] \\
\text { OAD-associated airway inflammation is associated with lower levels of SRAGE in CF patients } \\
\text { [22, 23] } \\
\text { None of the identified studies focused or included asthma as a clinical end-point }\end{array}$ \\
\hline Asthma & Positive & Negative & $\begin{array}{l}\text { Neutrophilic asthma in humans is associated with lower levels of sRAGE [13] } \\
\text { RAGE expression is associated with increased downstream inflammatory effects, reflective of } \\
\text { an asthmatic profile }[15,16]\end{array}$ \\
\hline COPD & Positive & Negative & $\begin{array}{l}\text { COPD is associated with RAGE overexpression }[48] \\
\text { sRAGE levels are reduced in COPD patients }[43] \\
\text { RAGE SNPs are positively associated with COPD }[55,56]\end{array}$ \\
\hline CVD & & Inconsistent & sRAGE and CVD outcome are inconsistent [44] \\
\hline WTC-LI & Positive & Positive & $\begin{array}{l}\text { Absence of RAGE is protective against loss of lung function in a murine model [6] } \\
\text { Increased SRAGE is associated with WTC-LI development [6] }\end{array}$ \\
\hline Pulmonary fibrosis & Negative & & $\mathrm{AGER}^{-/-}$mice develop fibrosis in an asbestos-exposure model [30] \\
\hline NO generation & Positive & Negative & $\begin{array}{l}\text { COPD smokers had higher RAGE and NO levels [47] } \\
\text { In vitro cigarette smoke exposure led to low SRAGE and high RAGE and NO levels [47] }\end{array}$ \\
\hline FEV 1 and $F_{E V} / F V C$ & Positive & Inconsistent & $\begin{array}{l}\text { Ser82 RAGE variant is associated with higher FEV } 1 \text { [57] } \\
\text { Lower sRAGE levels are associated with longitudinal decline of FEV1 in COPD smokers and } \\
\text { FEV } 1 / \text { FVC in all subjects [46] } \\
\text { COPD patients with lower sRAGE levels had higher FEV } 1 \text { [43] }\end{array}$ \\
\hline
\end{tabular}

OAD: obstructive airways disease; COPD: chronic obstructive pulmonary disease; CVD: cardiovascular disease; WTC-LI: World Trade Center lung injury; NO: nitric oxide; FEV1: forced expiratory volume in $1 \mathrm{~s}$; FVC: forced vital capacity; CF: cystic fibrosis; SNP: single nucleotide polymorphism; AGER: advanced glycation end-products receptor.

revealed similar findings in the cigarette smoke-exposed mice. The investigators concluded that COPD patients and cigarette smoke-exposed mice have pulmonary and renal endothelial cell injury associated with the tissue oxidative stress AGE-RAGE pathway [42].

Correlation of RAGE and nitric oxide generation

The role of RAGE in cigarette smoke-induced nitric oxide (NO) generation was studied by assessing the bronchial epithelia of smokers with COPD and compared to healthy smokers and nonsmokers with COPD. RAGE overexpression was noted only in smokers with COPD and positively correlated with NO levels, smoking status and lung function decline. Human bronchial epithelial cells that were cultured in cigarette smoke extract had low sRAGE levels, but enhanced RAGE and NO levels. Interestingly, increased NO level and NO synthase activity were all reversed by pretreatment with anti-RAGE antibody [47].

\section{Accumulation of RAGE in different body compartments}

One study assessed AGE and sRAGE levels in plasma, sputum, bronchial biopsies and skin and tested whether differential tissue accumulation is associated with COPD [43]. Skin autofluorescence of AGE and sRAGE in blood and sputum was measured by ELISA, and by immunohistochemistry in the bronchial biopsies. COPD patients had increased accumulation of AGE in the skin compared to non-COPD smokers and never-smokers. This difference in expression was not seen in bronchial tissues of different groups. Lower FEV 1 \% predicted and FEV1/FVC ratio were independently associated with a higher AGE levels in skin [43]. sRAGE levels were significantly lower in the plasma of COPD patients compared to young and old healthy subjects. Additionally, these levels were negatively correlated with the severity of COPD. Patients with lower sRAGE levels had lower FEV1, lower DLCO and higher AGE accumulation in the skin. The authors hypothesised that sRAGE has a protective effect and functions as a decoy receptor, preventing accumulation of AGE in the skin [43]. 
RAGE as a biomarker of cardiovascular disease in COPD

The results of studies assessing sRAGE and cardiovascular disease are heterogeneous. One study looked specifically at COPD patients and non-COPD smokers with calculated cardiovascular risk prediction scores [44]. The cardiovascular risk prediction scores and sRAGE levels were the same in both groups. They found no associations between sRAGE and diabetes or aortic pulse wave velocity [44]. In the absence of ischaemic heart disease or diabetes, COPD patients had significantly lower levels of sRAGE, which is consistent with prior literature.

\section{SRAGE as a marker of longitudinal loss of lung function}

A longitudinal cohort study of nonsmokers, smokers without COPD and smokers with COPD in northern Finland was performed with measurements of high mobility group box (HMGB)1 (a ligand of RAGE), sRAGE, and lung function testing. There were no significant differences in the HMGB1 levels between the study groups, but patients with severe airflow obstruction had higher levels than others [46]. This result is consistent with prior findings. Lower sRAGE levels were associated with longitudinal decline of FEV1/FVC ratio in all groups (table 2). This was particularly evident in smokers with COPD, as lower sRAGE levels predicted longitudinal decline in FEV1.

\section{Genetic polymorphism of RAGE in COPD}

The genetic polymorphism of RAGE is less well studied in COPD compared to inflammatory diseases such as Crohn's disease. There are 1517 single nucleotide polymorphisms (SNPs) detected in the RAGE gene, but they are mostly nonsense mutations [56]. Three functional SNPs in the promoter region $(-429$ T/C and -374 T/A) and one SNP in exon 3 (G82S) of the AGER gene have been studied. One study in a Chinese population showed that G82S polymorphism was significantly higher in COPD patients and associated with higher risk of developing COPD in current smokers [56]. In another study of a Polish population with severe COPD, a number of SNPs associated with lung function were investigated including AGER, ADCY2 and THSD4. They identified associations between CHRNA3/5, IREB2, FAM13A and COPD, as well as ADCY2 with severe COPD [55]. A GWAS on two quantitative emphysema and airway imaging phenotypes using the COPDGene, ECLIPSE, National Emphysema Treatment Trial (NETT) and Genetics of Chronic Obstructive Lung Disease (GenKOLS) cohorts found five loci of interest. AGER was associated with COPD and spirometric measures related to airflow obstruction as well as emphysema and sRAGE levels [54]. Furthermore, the Ser82 RAGE variant was associated with higher FEV1, FEV1/FVC ratio and lower serum sRAGE levels in UK smokers. The investigators also found that HMGB1 activation of the RAGE-Ser82 receptor resulted in lower sRAGE levels.

\section{RAGE as a biomarker of asthma}

Although asthma was not the clinical focus of any of the studies that met all inclusion/exclusion criteria of our systematic review, the development of an asthmatic phenotype may occur in the context of an environmental exposure. In the review of this literature we found that patients with neutrophilic asthma and COPD had significantly lower levels of sRAGE in BAL, plasma and serum relative to healthy controls and those with non-neutrophilic asthma and COPD. HMGB1, a potent mediator of neutrophilic inflammatory response and a RAGE ligand, was slightly increased in neutrophilic patients. Consistent with our understanding of the role of sRAGE, lack of inhibition of downstream inflammatory effects of RAGE may play a role in development of neutrophilic asthma [13]. In addition, RAGE has been implicated in the pathophysiology of eosinophilic asthma. In a murine model, wild-type (WT) and RAGE knockout mice were exposed to house dust mite (HDM) extract and sensitised with ovalbumin. HDM-exposed WT mice exhibited increased airway resistance and small airway tissue damping in response to methacholine challenge relative to RAGE knockouts. Absence of RAGE was associated with absence of inflammatory infiltrates, lack of elevated mucin expression or goblet cell hyperplasia. IL-5, IL-13 and eotaxin were significantly elevated in HDM-exposed WT mice, and to a lesser degree in RAGE knockout mice [15]. In another murine study, WT and RAGE knockout mice were sensitised with ovalbumin. The WT mice exhibited significantly elevated levels of interferon- $\gamma$ and IL-5 when compared to RAGE knockout mice [16] (table 2).

\section{Discussion}

Our systematic review identified 19 original articles where the role of RAGE is found to be important in the development of environmental exposure related OAD. These studies differed significantly in the populations, methods and outcomes that were studied (table 1). However, these studies allow us to further define the role of RAGE in the development of OAD related to a heterogeneous environmental exposure. These studies suggest that RAGE may be a multifaceted contributor to OAD development.

Particulate matter exposure causes systemic inflammation, endothelial dysfunction and subsequent end-organ damage leading to OAD [58-60]. These effects are particularly evident as loss of lung function 
associated with WTC-PM exposure [61-72]. There is mounting evidence that RAGE is a biologically plausible mediator of inflammation and vascular injury, and is associated with conditions such as metabolic syndrome and OAD.

In most organs, RAGE is expressed at low baseline levels and increases with disease activity as seen in the lungs of COPD patients [4]. The highest expression of RAGE occurs in the lungs, but its deleterious effects are not just limited to this organ. For instance, AGE-RAGE levels are elevated in the pulmonary and renal endothelial cells of patients with COPD [42]. Accumulation of AGEs in different organs appears to vary and correlates with the levels of circulating sRAGE. A prior study showed that accumulation of AGEs in the skin is directly correlated with low circulating sRAGE levels in COPD patients. This has led to the hypothesis that sRAGE acts a decoy receptor and appears to be protective against the inflammatory effect of membrane bound RAGE. Patients with higher PM exposure and associated COPD have lower levels of sRAGE. These levels correlate well with severity of COPD and predict longitudinal decline in FEV1 (tables 1 and 2).

A finer understanding of the RAGE pathway and its role in inflammation-associated OAD may allow us to identify therapeutic targets to halt progression of diseases such COPD. In one study, administration of sRAGE or deletion of the RAGE gene mitigated LPA-RAGE interaction and disease development [33]. RAGE has been the focus of targeted therapeutic trials [9, 73-75].

RAGE is a key mediator of MetSyn, which affects $>30 \%$ of adults in the United States [76-78]. A diet high in caloric content is a key contributor to MetSyn. Several groups are actively studying the MetSyn and lung disease associated with environmental exposures. Several studies of WTC-exposed cohorts (a high particulate exposed group) have described a high incidence of obesity [77, 79]. In addition, we found that a multimetabolite model was able to differentiate between those with WTC-LI and those without [72]. One of the key mediators of the metabolome is diet, and we know that dietary interventions that have focused on weight loss in obstructed patients show improvement of both FEV1 and FVC by as much as $22 \%$ in as little as 15 days $[80,81]$. Using a very low calorie diet, investigators have been able to achieve a $20 \mathrm{~kg}$ loss over a 6-month period; every $10 \%$ relative loss of weight led to a significant improvement of FVC by $92 \mathrm{~mL}$ and FEV1 by $73 \mathrm{~mL}$ [82]. As patients decreased their body mass index from 37 to $32 \mathrm{~kg} \cdot \mathrm{m}^{-2}$, the mean morning FEV1 and FVC significantly increased [83]. Improvement of lung function in obese subjects who undergo weight loss is due predominantly to changes in lung mechanics. Associated biochemical changes that may play a role are active areas of investigation and are a focus of our future work. Additionally, recent studies show the effectiveness of calorie-reduced and Mediterranean diets in reducing lipid levels [84]. While moderating fats can be essential to maintaining a healthy diet, there is extensive literature that explores the potential health benefits of high fats in a Mediterranean diet, such as n-3 and n-6 polyunsaturated fatty acids $[85,86]$.

Systematic reviews have inherent biases that we addressed through the design of our search algorithm. Our systematic review is affected by selection, detection, performance and reporting bias. Selection bias was addressed by having a predetermined inclusion and exclusion criteria and distinct definitions. Detection and performance bias were addressed by having at least two rounds of screening individually performed. Reporting bias was addressed through PubMed and Embase search filters that included peer-reviewed published articles that were written in English and which focused on human subjects. Removing duplicates further limited reporting bias.

The development of $\mathrm{OAD}$ due to environmental exposure is a leading cause of morbidity and mortality worldwide. RAGE is involved in the inflammatory cascade of events that lead to development of obstructive airway disease. Soluble RAGE acts as a decoy receptor and may have a protective effect against development of OAD. Patients with lower levels of soluble RAGE may have more severe COPD and emphysema. By targeting RAGE-mediated inflammation, we may mitigate progression of OAD.

Authors' contributions: All authors made substantial contributions to the study. All authors participated in study conception and design, data analysis and interpretation, and manuscript preparation. Primary investigator AN; study design SHH, EJC, AN; statistical analysis SHH; data interpretation SHH, AO, JR, AV, AN. All authors participated in writing and revision of the report and approval of the final version.

Author disclaimers: The views expressed in this article do not communicate an official position of the institution, or funding source.

Conflict of interest: None declared.

Support statement: NHLBI R01HL119326, CDC/NIOSH U01-OH011300. The funding agencies did not participate in the study design; collection, analysis and interpretation of data; in the writing of the report; and in the decision to submit the article for publication. Funding information for this article has been deposited with the Crossref Funder Registry. 


\section{References}

1 Ling SH, van Eeden SF. Particulate matter air pollution exposure: role in the development and exacerbation of chronic obstructive pulmonary disease. Int J Chron Obstruct Pulmon Dis 2009; 4: 233-243.

2 Dockery DW, Pope CA, Xu X, et al. An association between air pollution and mortality in six U.S. cities. $N$ Engl Med 1993; 329: 1753-1759.

3 Schwartz J. Short term fluctuations in air pollution and hospital admissions of the elderly for respiratory disease. Thorax 1995; 50: 531-538.

4 Wu L, Ma L, Nicholson LF, et al. Advanced glycation end products and its receptor (RAGE) are increased in patients with COPD. Respir Med 2011; 105: 329-336.

5 Penyige A, Poliska S, Csanky E, et al. Analyses of association between PPAR gamma and EPHX1 polymorphisms and susceptibility to COPD in a Hungarian cohort, a case-control study. BMC Med Genet 2010; 11: 152.

6 Caraher EJ, Kwon S, Haider SH, et al. Receptor for advanced glycation end-products and World Trade Center particulate induced lung function loss: a case-cohort study and murine model of acute particulate exposure. PLoS One 2017; 12: e0184331.

7 Katsuoka F, Kawakami Y, Arai T, et al. Type II alveolar epithelial cells in lung express receptor for advanced glycation end products (RAGE) gene. Biochem Biophys Res Commun 1997; 238: 512-516.

8 Buckley ST, Ehrhardt C. The receptor for advanced glycation end products (RAGE) and the lung. J Biomed Biotechnol 2010; 2010: 917108.

9 Yan SF, Ramasamy R, Schmidt AM. The RAGE axis: a fundamental mechanism signaling danger to the vulnerable vasculature. Circ Res 2010; 106: 842-853.

$10 \mathrm{Ge} \mathrm{X}, \mathrm{Xu} \mathrm{XY}$, Feng $\mathrm{CH}$, et al. Relationships among serum C-reactive protein, receptor for advanced glycation products, metabolic dysfunction, and cognitive impairments. BMC Neurol 2013; 13: 110

11 Kierdorf K, Fritz G. RAGE regulation and signaling in inflammation and beyond. J Leukoc Biol 2013; 94: 55-68.

12 Sukkar MB, Ullah MA, Gan WJ, et al. RAGE: a new frontier in chronic airways disease. Br J Pharmacol 2012; 167: $1161-1176$.

13 Sukkar MB, Wood LG, Tooze M, et al. Soluble RAGE is deficient in neutrophilic asthma and COPD. Eur Respir J 2012; 39: 721-729.

14 Yonchuk JG, Silverman EK, Bowler RP, et al. Circulating soluble receptor for advanced glycation end products (sRAGE) as a biomarker of emphysema and the RAGE axis in the lung. Am J Respir Crit Care Med 2015; 192: 785-792.

15 Milutinovic PS, Alcorn JF, Englert JM, et al. The receptor for advanced glycation end products is a central mediator of asthma pathogenesis. Am J Pathol 2012; 181: 1215-1225.

16 Akirav EM, Henegariu O, Preston-Hurlburt P, et al. The receptor for advanced glycation end products (RAGE) affects T cell differentiation in OVA induced asthma. PLoS One 2014; 9: e95678.

17 Sambamurthy N, Leme AS, Oury TD, et al. The receptor for advanced glycation end products (RAGE) contributes to the progression of emphysema in mice. PLoS One 2015; 10: e0118979.

18 Ferhani N, Letuve S, Kozhich A, et al. Expression of high-mobility group box 1 and of receptor for advanced glycation end products in chronic obstructive pulmonary disease. Am J Respir Crit Care Med 2010; 181: 917-927.

19 Hancock DB, Eijgelsheim M, Wilk JB, et al. Meta-analyses of genome-wide association studies identify multiple loci associated with pulmonary function. Nat Genet 2010; 42: 45-52.

20 Repapi E, Sayers I, Wain LV, et al. Genome-wide association study identifies five loci associated with lung function. Nat Genet 2010; 42: 36-44.

21 Beucher J, Boëlle PY, Busson, PF, et al. AGER -429 T/C is associated with an increased lung disease severity in cystic fibrosis. PLoS One 2012; 7: e41913.

22 Corvol H, Beucher, J Boëlle, PY, et al. Ancestral haplotype 8.1 and lung disease severity in European cystic fibrosis patients. J Cyst Fibros 2012; 11: 63-67.

23 Laki J, Laki I, Németh, K, et al. The 8.1 ancestral MHC haplotype is associated with delayed onset of colonization in cystic fibrosis. Int Immunol 2006; 18: 1585-1590.

24 Schmidt AM. Soluble RAGEs - prospects for treating \& tracking metabolic and inflammatory disease. Vascul Pharmacol 2015; 72: 1-8.

25 Jabaudon M, Blondonnet R, Roszyk L, et al. Soluble receptor for advanced glycation end-products predicts impaired alveolar fluid clearance in acute respiratory distress syndrome. Am J Respir Crit Care Med 2015; 192: 191-199.

26 Zhang H, Tasaka S, Shiraishi Y, et al. Role of soluble receptor for advanced glycation end products on endotoxin-induced lung injury. Am J Respir Crit Care Med 2008; 178: 356-362.

27 Su X, Looney MR, Gupta N, et al. Receptor for advanced glycation end-products (RAGE) is an indicator of direct lung injury in models of experimental lung injury. Am J Physiol Lung Cell Mol Physiol 2009; 297: L1-L5.

28 Englert JM, Hanford LE, Kaminski N, et al. A role for the receptor for advanced glycation end products in idiopathic pulmonary fibrosis. Am J Pathol 2008; 172: 583-591.

29 Hanford LE, Fattman CL, Shaefer LM, et al. Regulation of receptor for advanced glycation end products during bleomycin-induced lung injury. Am J Respir Cell Mol Biol 2003; 29: Suppl. 3, S77-S81.

30 Ramsgaard L, Englert JM, Tobolewski J, et al. The role of the receptor for advanced glycation end-products in a murine model of silicosis. PLoS One 2010; 5: e9604.

31 He M, Kubo $\mathrm{H}$, Ishizawa $\mathrm{K}$, et al. The role of the receptor for advanced glycation end-products in lung fibrosis. Am J Physiol Lung Cell Mol Physiol 2007; 293: L1427-L1436.

32 Song F, Hurtado del Pozo C, Rosario R, et al. RAGE regulates the metabolic and inflammatory response to high-fat feeding in mice. Diabetes 2014; 63: 1948-1965.

33 Rai V, Touré F, Chitayat S, et al. Lysophosphatidic acid targets vascular and oncogenic pathways via RAGE signaling. J Exp Med 2012; 209: 2339-2350.

34 Tsukiji J, Cho SJ, Echevarria GC, et al. Lysophosphatidic acid and apolipoprotein A1 predict increased risk of developing World Trade Center-lung injury: a nested case-control study. Biomarkers 2014; 19: 159-165.

35 Liberati A, Altman DG, Tetzlaff J, et al. The PRISMA statement for reporting systematic reviews and meta-analyses of studies that evaluate health care interventions: explanation and elaboration. Ann Intern Med 2009; 151: W65-W94. 
36 Shamseer L, Moher D, Clarke M, et al. Preferred reporting items for systematic review and meta-analysis protocols (PRISMA-P) 2015: elaboration and explanation. BMJ 2015; 350: g7647.

37 Hagstad S, Bjerg A, Ekerljung L, et al. Passive smoking exposure is associated with increased risk of COPD in never smokers. Chest 2014; 145: 1298-1304.

38 Salvi S. Tobacco smoking and environmental risk factors for chronic obstructive pulmonary disease. Clin Chest Med 2014; 35: 17-27.

39 Yin P, Jiang CQ, Cheng KK, et al. Passive smoking exposure and risk of COPD among adults in China: the Guangzhou Biobank Cohort Study. Lancet 2007; 370: 751-757.

40 Moher D, Liberati A, Tetzlaff J, et al. Preferred reporting items for systematic reviews and meta-analyses: the PRISMA statement. BMJ 2009; 339: b2535.

41 Lee KY, Chiang LL, Ho SC, et al. Associations of autophagy with lung diffusion capacity and oxygen saturation in severe COPD: effects of particulate air pollution. Int J Chron Obstruct Pulmon Dis 2016; 11: 1569-1578.

42 Polverino F, Laucho-Contreras ME, Petersen $\mathrm{H}$, et al. A pilot study linking endothelial injury in lungs and kidneys in chronic obstructive pulmonary disease. Am J Respir Crit Care Med 2017; 195: 1464-1476.

43 Hoonhorst SJM, Lo Tam Loi AT, Pouwels SD, et al. Advanced glycation endproducts and their receptor in different body compartments in COPD. Respiratory Res 2016; 17: 46.

44 John M, McKeever TM, Haddad MA, et al. Traditional and emerging indicators of cardiovascular risk in chronic obstructive pulmonary disease. Chron Respir Dis 2016; 13: 247-255.

45 Carolan BJ, Hughes G, Morrow J, et al. The association of plasma biomarkers with computed tomography-assessed emphysema phenotypes. Respir Res 2014; 15: 127.

46 Iwamoto H, Gao J, Pulkkinen V, et al. Soluble receptor for advanced glycation end-products and progression of airway disease. BMC Pulm Med 2014; 14: 68.

47 Chen L, Wang T, Guo L, et al. Overexpression of RAGE contributes to cigarette smoke-induced nitric oxide generation in COPD. Lung 2014; 192: 267-275.

48 Coxson HO, Dirksen A, Edwards LD, et al. The presence and progression of emphysema in COPD as determined by CT scanning and biomarker expression: a prospective analysis from the ECLIPSE study. Lancet Respir Med 2013; 1: 129-136.

49 Cockayne DA, Cheng DT, Waschki B, et al. Systemic biomarkers of neutrophilic inflammation, tissue injury and repair in COPD patients with differing levels of disease severity. PLoS One 2012; 7: e38629.

50 Miniati M, Monti S, Basta G, et al. Soluble receptor for advanced glycation end products in COPD: relationship with emphysema and chronic cor pulmonale: a case-control study. Respir Res 2011; 12: 37.

51 Ohlmeier S, Mazur W, Salmenkivi K, et al. Proteomic studies on receptor for advanced glycation end product variants in idiopathic pulmonary fibrosis and chronic obstructive pulmonary disease. Proteomics Clin Appl 2010; 4: $97-105$.

52 Zhang Y, Li S, Wang G, et al. Changes of HMGB1 and sRAGE during the recovery of COPD exacerbation. J Thorac Dis 2014; 6: 734-741.

53 Boschetto P, Campo I, Stendardo M, et al. Plasma sRAGE and N-(carboxymethyl) lysine in patients with CHF and/or COPD. Eur J Clin Invest 2013; 43: 562-569.

54 Cho MH, Castaldi PJ, Hersh CP, et al. A genome-wide association study of emphysema and airway quantitative imaging phenotypes. Am J Respir Crit Care Med 2015; 192: 559-569.

55 Hardin M, Zielinski J, Wan ES, et al. CHRNA3/5, IREB2, and ADCY2 are associated with severe chronic obstructive pulmonary disease in Poland. Am J Respir Cell Mol Biol 2012; 47: 203-208.

56 Li Y, Yang C, Ma G, et al. Association of polymorphisms of the receptor for advanced glycation end products gene with COPD in the Chinese population. DNA Cell Biol 2014; 33: 251-258.

57 Miller S, Henry AP, Hodge E, et al. The Ser82 RAGE variant affects lung function and serum RAGE in smokers and sRAGE production in vitro. PLoS One 2016; 11: e0164041.

58 Naveed B, Weiden MD, Kwon S, et al. Metabolic syndrome biomarkers predict lung function impairment: a nested case-control study. Am J Respir Crit Care Med 2012; 185: 392-399.

59 Gosker HR, Schrauwen P, Broekhuizen R, et al. Exercise training restores uncoupling protein-3 content in limb muscles of patients with chronic obstructive pulmonary disease. Am J Physiol Endocrinol Metab 2006; 290 : E976-E981.

60 Gan WQ, Man SF, Senthilselvan A, et al. Association between chronic obstructive pulmonary disease and systemic inflammation: a systematic review and a meta-analysis. Thorax 2004; 59: 574-580.

61 Prezant DJ, Weiden M, Banauch GI, et al. Cough and bronchial responsiveness in firefighters at the World Trade Center site. N Engl J Med 2002; 347: 806-815

62 Banauch GI, Dhala A, Alleyne D, et al. Bronchial hyperreactivity and other inhalation lung injuries in rescue/ recovery workers after the World Trade Center collapse. Crit Care Med 2005; 33: Suppl. 1, S102-S106.

63 Banauch GI, Hall C, Weiden M, et al. Pulmonary function after exposure to the World Trade Center collapse in the New York City Fire Department. Am J Respir Crit Care Med 2006; 174: 312-319.

64 Feldman DM, Baron SL, Bernard BP, et al. Symptoms, respirator use, and pulmonary function changes among New York City firefighters responding to the World Trade Center disaster. Chest 2004; 125: 1256-1264.

65 Banauch GI, Alleyne D, Sanchez R, et al. Persistent hyperreactivity and reactive airway dysfunction in firefighters at the World Trade Center. Am J Respir Crit Care Med 2003; 168: 54-62.

66 Felipe A, Artigas JM, Díez-Ajenjo A, et al. Residual astigmatism produced by toric intraocular lens rotation. J Cataract Refract Surg 2011; 37: 1895-1901.

67 Xiao B, Su M, Kim EL, et al. Synthesis of PPAR- $\gamma$ activators inspired by the marine natural product, paecilocin A. Mar Drugs 2014; 12: 926-939.

68 Herbert R, Moline J, Skloot G, et al. The World Trade Center disaster and the health of workers: five-year assessment of a unique medical screening program. Environ Health Perspect 2006; 114: 1853-1858.

69 Reibman J, Lin S, Hwang SA, et al. The World Trade Center residents' respiratory health study: new-onset respiratory symptoms and pulmonary function. Environ Health Perspect 2005; 113: 406-411.

70 Self-reported increase in asthma severity after the September 11 attacks on the World Trade Center - Manhattan, New York, 2001. JAMA 2002; 288: 1466-1467.

71 Self-reported increase in asthma severity after the September 11 attacks on the World Trade Center - Manhattaan, New York, 2001. MMWR Morb Mortal Wkly Rep 2002; 51: 781-784. 
72 Crowley G, Kwon S, Haider SH, et al. Metabolomics of World Trade Center-Lung Injury: a machine learning approach. BMJ Open Respir Res 2018; 5: e000274.

73 Yan SF, Ramasamy R, Schmidt AM. Soluble RAGE: therapy and biomarker in unraveling the RAGE axis in chronic disease and aging. Biochem Pharmacol 2010; 79: 1379-1386.

74 Yan SF, Ramasamy R, Schmidt AM. The receptor for advanced glycation endproducts (RAGE) and cardiovascular disease. Expert Rev Mol Med 2009; 11: e9.

75 Yan SF, Yan SD, Ramasamy R, et al. Tempering the wrath of RAGE: an emerging therapeutic strategy against diabetic complications, neurodegeneration, and inflammation. Ann Med 2009; 41: 408-422.

76 Chen JC, Schwartz J. Metabolic syndrome and inflammatory responses to long-term particulate air pollutants. Environ Health Perspect 2008; 116: 612-617.

77 Aldrich TK, Gustave J, Hall CB, et al. Lung function in rescue workers at the World Trade Center after 7 years. N Engl J Med 2010; 362: 1263-1272.

78 Webber MP, Lee R, Soo J, et al. Prevalence and incidence of high risk for obstructive sleep apnea in World Trade Center-exposed rescue/recovery workers. Sleep Breath 2011; 15: 283-294.

79 Skloot GS, Schechter CB, Herbert R, et al. Longitudinal assessment of spirometry in the World Trade Center medical monitoring program. Chest 2009; 135: 492-498.

80 Angelillo VA, Bedi S, Durfee D, et al. Effects of low and high carbohydrate feedings in ambulatory patients with chronic obstructive pulmonary disease and chronic hypercapnia. Ann Intern Med 1985; 103: 883-885.

81 McDonald VM, Gibson PG, Scott HA, et al. Should we treat obesity in COPD? The effects of diet and resistance exercise training. Respirology 2016; 21: 875-882.

82 Aaron SD, Fergusson D, Dent R, et al. Effect of weight reduction on respiratory function and airway reactivity in obese women. Chest 2004; 125: 2046-2052.

83 Hakala K, Stenius-Aarniala B, Sovijärvi A. Effects of weight loss on peak flow variability, airways obstruction, and lung volumes in obese patients with asthma. Chest 2000; 118: 1315-1321.

84 Shai I, Schwarzfuchs D, Henkin Y, et al. Weight loss with a low-carbohydrate, Mediterranean, or low-fat diet. N Engl J Med 2008; 359: 229-241.

85 Schwartz J. Role of polyunsaturated fatty acids in lung disease. Am J Clin Nutr 2000; 71: Suppl. 1, 393S-396S

86 Seegmiller AC. Abnormal unsaturated fatty acid metabolism in cystic fibrosis: biochemical mechanisms and clinical implications. Int J Mol Sci 2014; 15: 16083-16099. 